\begin{tabular}{|l|l|l|l|l|l|}
\hline J. Tek. Ling & Vol. 12 & No. 1 & Hal. 7 - 16 & Jakarta, Januari 2011 & ISSN 1441-318X \\
\hline
\end{tabular}

\title{
EVALUASI PROSES PRODUKSI PUPUK ORGANIK GRANUL (POG) YANG DIPERKAYA DENGAN MIKROBA FUNGSIONAL
}

\author{
Firman L. Sahwan, Sri Wahyono dan Feddy Suryanto \\ Peneliti di Pusat Teknologi Lingkungan \\ Badan Pengkajian dan Penerapan Teknologi
}

\begin{abstract}
Organic Fertilizer in the form of Granule Organic Fertilizer (POG), which is enriched with functional microbes, has been produced in great quantities nowdays, because it is expected to improve the physical, chemical, and biological properties of soil at once. The condition of land degradation that has become a big concern, in spite of the low organic matter in the lands, more encourage the increasing of $P O G$ production to be applied very soon into agricultural lands in Indonesia. However, how is the conditions of the POG plant, what kind of raw material that will be used and how does the production process itself run, would be very excited to be analysis in order to develop the future of POG plant. Results showed that the POG plant conditions generally contains of the facilities and infrastructure that support the physical/ mechanical process, that is not passed the biological process first which is known as composting process. The raw materials that has been used could not maximize organic materials potentials that exist and only rely on animal waste and sugarcane waste (blotong) from sugar mills, as the main mostly used raw material. While the common POG manufacturing process consist of the mixing of the raw materials, granulation process, drying, cooling, screening, enrichment with functional microbes and packaging.
\end{abstract}

Key Words: Granule organic fertilizer, microbe, organic material, composting, physical process, biological process.

\section{PENDAHULUAN}

\subsection{Latar Belakang}

Pupuk organik granul merupakan pupuk organik yang diproses lebih lanjut sehingga menjadi berbentuk butiran atau granul. Sedangkan yang dimaksud dengan pupuk organik adalah pupuk yang berasal dari sisa tanaman dan/atau kotoran hewan yang telah melalui proses rekayasa, berbentuk padat atau cair dan dapat diperkaya dengan bahan mineral alami dan/atau mikroba yang bermanfaat memperkaya hara, bahan organik tanah, dan memperbaiki sifat fisik, kimia dan biologi tanah ${ }^{1}$. Berbagai macam istilah atau nama dari pupuk organik kita kenal. Namun secara umum dapat dikelompokkan menjadi 3 (tiga), dan dikenal dengan nama pupuk kandang, pupuk hijau dan kompos. Pupuk kandang merupakan pupuk organik yang berasal dari kotoran ternak, yang biasanya didiamkan terlebih dahulu dengan cara ditumpuk selama 1,5-2 bulan, sebelum 
digunakan sebagai pupuk pada tanaman. Pupuk hijau merupakan pupuk organik yang berasal dari daun-daunan, terutama dari daun tanaman kacang-kacangan (leguminosa), yang penggunaannya dengan cara dibenamkan ke dalam tanah. Sedangkan kompos merupakan pupuk organik berupa materi yang sederhana dan relatif stabil yang dihasilkan dari suatu proses dekomposisi (penguraian) berbagai materi organik yang kompleks secara biologis oleh konsorsium mikroorganisme dalam kondisi aerobik dan termofilik yang terkendali ${ }^{2,3,4,5 \& 6)}$. Untuk mendapatkan pupuk organik yang baik, maka sebaiknya bahan organik yang ada diproses terlebih dahulu melalui proses pengomposan, sampai diperoleh kompos yang memenuhi kriteria kompos matang dan siap digunakan oleh pertanian tanaman pangan, perkebunan, hortikultura, peternakan, perikanan, kehutanan dan lain-lain.

Pupuk organik merupakan pupuk yang seharusnya sangat diandalkan, karena dapat memperbaiki sifat fisik, kimia dan biologi tanah secara sekaligus. Persepsi tersebut begitu mencuat pada akhir-akhir ini. Faktor-faktor yang mempengaruhi adalah: meningkatnya pemahaman yang benar mengenai fungsi pupuk organik; kerusakan lingkungan termasuk kerusakan tanah-tanah pertanian; meningkatnya pencemaran lingkungan (tanah, udara, dan air) akibat penggunaan agrochemical yang berlebihan; makin mahal dan makin sukarnya memperoleh bahan baku pupuk buatan; meningkatnya permintaan terhadap produk pertanian organik; dan bahan baku pupuk organik yang banyak tersedia secara lokal dan terbarukan ${ }^{7)}$. Faktor lain seperti rendahnya bahan organik tanah, yakni 65 $\%$ dari 7,9 juta ha lahan sawah di Indonesia memiliki kandungan bahan organik rendah sampai sangat rendah (C-organik<2 \%) ${ }^{8)}$, serta kebijakan Go Organik $2010^{9)}$, semakin memacu penggunaan pupuk organik.

Pupuk organik kemudian diproses lebih lanjut menjadi Pupuk Organik Granul (POG), dengan tujuan untuk memudahkan para petani pada saat menggunakan, efisiensi dalam penggunaan, selain faktor kebiasaan petani yang sudah terbiasa menggunakan pupuk kimia (anorganik) berbentuk granul. Di sini tersirat bahwa target utamanya adalah untuk memberi kemudahan kepada para petani, sehingga mau menggunakan dan akhirnya terbiasa dengan penggunaan pupuk organik.

Saat ini, POG banyak diproduksi dalam rangka memenuhi kebutuhan atau permintaan dari Kementerian Pertanian. Umumnya POG yang diproduksi merupakan POG yang diperkaya dengan mikroba fungsional, yang pada dasarnya terdiri dari 2 (dua) jenis kelompok mikroba, yaitu penambat $\mathrm{N}$ (Nitrogen) dan pelarut $\mathrm{P}$ (Phosfat). Dari 2 (dua) jenis kelompok tersebut, selain fungsi utamanya sebagai penyedia hara, ada juga yang mempunyai kemampuan sebagai pemacu pertumbuhan tanaman, dengan mensintesis berbagai zat pengatur tumbuh (phytohormone), serta kemampuan sebagai pengendali patogen yang berasal dari tanah ${ }^{10)}$. Banyaknya POG yang diproduksi, terlihat dari alokasi POG bersubsidi, tahun 2009 sebesar 0,45 juta ton dan tahun 2010 dialokasikan 0,91 juta ton. Sedangkan untuk POG bantuan langsung, tahun 2009 dialokasikan 0,19 juta ton dan tahun 2010 dialokasikan 0,29 juta ton. Jumlah tersebut untuk mendukung kebutuhan pupuk organik sebesar 4,67 juta ton untuk tahun 2009 dan 4,14 juta ton untuk tahun $2010{ }^{11}$. Banyaknya produksi POG tersebut, ada kaitannya dengan kebijakan Kementerian Pertanian, melalui Direktorat Jenderal Tanaman Pangan, tentang gerakan pengembangan pupuk organik untuk mendorong pengembangan usahatani berwawasan lingkungan melalui: sosialisasi penggunaan pupuk organik, bantuan langsung pupuk organik, bantuan alat pembuat pupuk organik dan rumah percontohan pembuatan pupuk organik, serta subsidi pupuk organik ${ }^{11)}$.

Untuk menjaga kualitas dari produk POG, maka telah dikeluarkan Peraturan 
Menteri Pertanian Nomor 28 Tahun 2009 tentang pupuk organik, pupuk hayati dan pembenah tanah ${ }^{1)}$, yang menjadi panduan utama bagi produsen POG. Dengan panduan tersebut diharapkan kualitas POG bisa terjaga. POG yang berkualitas, juga sangat dipengaruhi oleh kualitas pupuk organik yang dijadikan bahan baku. Bahan baku tersebut sebaiknya berupa kompos matang (siap pakai) yang telah diproses melalui suatu proses pengomposan yang tepat. Untuk kondisi di Indonesia proses pengomposan yang paling optimal adalah sistem open windrow yang melibatkan kondisi aerobic dan thermophilic ${ }^{6}$. Dengan menggunakan metoda tersebut maka bahan baku kompos yang dibutuhkan dapat menggunakan seluruh bahan organik yang ada, dan tidak tergantung pada satu atau beberapa bahan organik saja. Hal ini penting untuk diperhatikan karena potensi berbagai bahan organik yang ada di Indonesia sangat tinggi.

Permasalahannya adalah belum semua bahan organik yang potensial telah dimanfaatkan menjadi kompos, yang selanjutnya dipakai sebagai bahan baku dalam pembuatan POG. Bahan baku POG kelihatannya hanya mengandalkan pupuk kandang atau bahan-bahan organik yang telah lapuk. Penelitian ini dilakukan untuk mengetahui permasalahan, kendala dan hal-hal yang melatar belakanginya.

\subsection{Tujuan Penelitian}

Penelitian ini dilakukan dengan tujuan untuk mengetahui dan menganalisis kondisi dari plant/pabrik POG, karakteristik bahan baku yang biasa dipakai, serta proses pembuatan untuk memproduksi POG.

\section{METODOLOGI}

\subsection{Tempat dan Waktu Penelitian}

Penelitian ini dilakukan di plant/pabrik pembuatan POG yang tersebar di Propinsi Jawa Barat, Banten, Jawa Tengah, Daerah
Istimewa Jogyakarta dan Jawa Timur.

Sedangkan waktu penelitian dilakukan pada bulan Juni 2010.

\subsection{Cara Penelitian}

Penelitian dilakukan dengan cara pengisian kuesioner yang secara garis besar dibagi ke dalam 3 (tiga) kelompok yaitu tentang plant/pabrik, bahan baku dan proses produksi. Pengisian kuesioner dilakukan langsung oleh 3 (tiga) orang peneliti yang dibagi ke dalam 3 (tiga) kelompok lokasi. Satu orang peneliti bertugas untuk Wilayah Jawa Bagian Barat, satu orang untuk Wilayah Jawa Bagian Tengah dan satu orang lagi untuk Wilayah Jawa Bagian Timur. Dengan sistem seperti ini maka para peneliti dapat melakukan wawancara dan observasi langsung di lapangan, sehingga penelitian dapat dilakukan lebih akurat.

Sedangkan jumlah plant/pabrik yang diteliti sebanyak 20 (dua puluh) buah, yang tersebar di tiga kelompok lokasi, yaitu 8 (delapan) pabrik berlokasi di Jawa Bagian Barat, 6 (enam) pabrik berlokasi di Jawa Bagian Tengah dan 6 (enam) lagi berlokasi di Jawa Bagian Timur.

Data yang diperoleh dari pengisian kuesioner dan observasi lapangan oleh masing-masing peneliti kemudian digabung menjadi (satu), untuk selanjutnya dilakukan analisis secara bersama-sama.

\section{HASIL DAN PEMBAHASAN}

\subsection{Kondisi Plant/Pabrik POG}

Untuk membuat POG yang berkualitas, seharusnya menggunakan kompos yang berkualitas, yaitu kompos yang dihasilkan dari proses dekomposisi materi organik secara aerobik dan termophilic yang terkendali ${ }^{2-6)}$. Untuk itu, sebaiknya plant POG dilengkapi juga dengan unit/plant pengomposan yang memenuhi kriteria untuk proses pengomposan yang baik, karena sekaligus berfungsi sebagai kontrol mutu 
dari produk kompos yang dihasilkan, yang selanjutnya digunakan sebagai bahan baku POG. Baik tidaknya kualitas POG, sangat tergantung dari kualitas kompos atau pupuk organik yang dijadikan sebagai bahan baku POG. Hasil observasi di lapangan menunjukkan bahwa tidak semua plant POG memiliki sarana pengomposan. Tercatat hanya sekitar $30 \%$ dari plant POG yang dilengkapi dengan plant pengomposan. Dari jumlah tersebut hanya $50 \%$ nya yang tercatat sebagai plant pengomposan yang baik, yaitu dilengkapi dengan atap dan lantainya disemen. Perlu pula diinformasikan bahwa fungsi plant pengomposan yang ada bukan untuk mengolah seluruh bahan baku organik yang ada, untuk kemudian diproses menjadi kompos. Plant pengomposan yang ada hanya untuk mengolah sebagian bahan baku yang dianggap masih belum terdekomposisi secara sempurna.

Minimnya sarana pengomposan pada plant/pabrik POG, sangat berkaitan dengan kebijakan pabrik dalam menggunakan bahan baku POG, yaitu lebih memilih menggunakan bahan baku yang bisa langsung diproses menjadi POG. Hal ini akan dibahas pada sub bab karakteristik bahan baku POG.

Luas dari plant/pabrik POG sangat bervariasi, mulai dari $100 \mathrm{~m}^{2}$ sampai 8.000 $\mathrm{m} 2$ dengan kemampuan kapasitas produksi juga bervariasi, mulai dari kapasitas 8 ton sampai 100 ton POG per hari. Plant/pabrik POG yang ada, semuanya dilengkapi dengan gudang yang berfungsi untuk menyimpan peralatan, bahan baku dan produk POG. Sebagian besar (58\%) dari pabrik POG memiliki fasilitas kantor yang dilengkapi dengan sarana pendukungnya seperti telpon, fax dan komputer. Sisanya, yaitu $25 \%$ memiliki kantor yang tidak dilengkapi dengan sarana pendukung dan $17 \%$ tidak memiliki kantor.

Peralatan utama yang umumnya dipakai untuk memproduksi POG antara lain :

- Crusher yang digunakan untuk menghancurkan kompos atau bahan baku POG yang masih kasar atau berbentuk bongkahan;

- Mesin penyaring (screen) pupuk organik berbentuk rotary screen atau vibrating screen dengan diameter saringan $3 \mathrm{~mm}$ yang berfungsi untuk menyaring bahan baku POG;

- Mixer untuk mencampur bahan baku POG dengan bahan-bahan pendukung (filler);

- Pan granulator untuk membentuk bahan baku menjadi berbentuk granul;

- Mesin pengering (rotary drier) untuk mengeringkan kadar air POG;

- Mesin pendingin (rotary cooler) untuk mendinginkan POG;

- Mesin penyaring (rotary atau vibrating screen) POG dengan saringan ganda berukuran 2 dan $5 \mathrm{~mm}$ untuk menyaring POG sehingga berukuran 2-5 mm;

- Unit pengayaan mikroba yang terdiri dari tangki aerasi, aerator, nozzle dan compressor.

Keberadaan peralatan-peralatan tersebut terutama dalam rangka untuk menghasilkan produk POG yang memenuhi persyaratan Permentan No.28 Tahun 2009. Bagi perusahaan atau pabrik POG yang menggunakan bahan baku yang sudah halus, maka pabrik tidak lagi melakukan proses penghancuran dan penyaringan bahan baku, sehingga mesin crusher dan penyaring menjadi tidak diperlukan. Selain peralatan utama, pabrik POG umumnya dilengkapi dengan peralatan pelengkap seperti mesin jahit karung, timbangan, kereta dorong dan lain-lain.

\subsection{Karakteristik Bahan Baku POG}

Pada umumnya bahan baku POG terdiri dari 2 (dua) bagian, yaitu bahan baku utama dan bahan baku tambahan atau pengisi yang biasa disebut dengan filler. Disebut bahan baku utama karena jumlahnya yang mendominasi dari keseluruhan bahan baku yaitu berkisar $80-90 \%$. Sedangkan filler yang 
umumnya terdiri dari dolomit, fosfat alam, kapur dan zeolit, jumlahnya hanya berkisar 10-20\%.

Para produsen POG, umumnya menggunakan bahan baku utama yang memiliki sifat sudah lapuk, halus dan kering, yang biasanya dipasok oleh perusahaan lain (mitra perusahaan). Dengan bahan baku yang seperti itu, maka produsen POG umumnya tidak melakukan proses pengomposan lagi dan langsung menggunakannya menjadi POG, dengan terlebih dahulu menambahkan dengan filler yang disukai. Bahan-bahan tersebut adalah : kotoran hewan (terutama sapi dan ayam), blotong (limbah pabrik gula), jerami bekas media budidaya jamur, cocopeat, limbah industri coklat, limbah pabrik penyedap masakan, limbah daun tembakau dan lain-lain.

Bahan baku utama yang selalu dipakai oleh pabrik POG adalah kotoran hewan (kohe). Kemudian bahan baku utama kedua, yaitu sekitar $75 \%$ pabrik POG menggunakan adalah blotong. Kedua bahan baku tersebut diminati karena bentuknya sudah halus, mudah diperoleh dan dapat diproses langsung menjadi POG. Urutan berikutnya adalah limbah jerami bekas media budidaya jamur yang dipakai oleh sekitar $40 \%$ pabrik POG. Sedangkan bahan baku yang lain, umumnya digunakan dalam jumlah sedikit dan biasanya bersifat temporer.

Secara ilmiah telah dinyatakan bahwa hampir semua bahan organik dapat dijadikan kompos ${ }^{2,3,4,5 \& 6)}$. Sedangkan kompos merupakan bahan baku yang baik untuk dijadikan POG. Namun pada proses pembuatan POG, jenis bahan organik yang digunakan sangat terbatas dan belum mengoptimalkan seluruh potensi bahan organik yang ada. Penyebab utamanya adalah karena umumnya pabrik POG memproduksi POG dalam rangka memenuhi kontrak dengan perusahaan yang ditunjuk oleh Kementerian Pertanian. Dalam proses produksi untuk memenuhi kontrak tersebut, biasanya waktu yang disediakan sangat singkat, sehingga sulit bagi pabrik POG untuk melakukan proses yang lain, selain langsung melakukan pembuatan POG dari bahan organik yang telah siap pakai menurut versi pihak pabrik POG. Selain itu, melakukan proses pengomposan terlebih dahulu, dianggap sebagai penambahan biaya produksi. Proses pengomposan terhadap bahan-bahan organik yang lain akan menjadi pilihan dikemudian hari, apabila bahanbahan yang sekarang menjadi pilihan utama, menjadi terbatas jumlahnya atau harganya menjadi lebih mahal.

Dengan menggunakan bahan baku secara langsung dari pemasok yang telah ditentukan, sebenarnya pihak pabrik POG agak sulit mengontrol kualitas bahan baku pupuk organik yang diterimanya. Apalagi para pemasok umumnya tidak melakukan proses pengomposan yang baik terlebih dahulu terhadap pupuk organik yang dihasilkannya, sehingga sulit menyatakan bahwa pupuk organik yang dihasilkan adalah pupuk organik yang benar-benar telah siap pakai oleh tanaman. Pengamatan di lapangan menunjukkan bahwa evaluasi kualitas yang dilakukan oleh pihak pabrik lebih mengandalkan kepada faktor kepercayaan kepada pihak pemasok, yaitu pupuk organik yang dipasoknya merupakan bahan baku yang sudah lama dan sudah melapuk. Bagi pihak pabrik, kriteria tersebut sebenarnya sulit untuk mengevaluasinya, terutama untuk pupuk organik/bahan baku yang sudah berbentuk halus dari awal, seperti kotoran hewan, blotong dan lain-lain.

Dari pengamatan di lapangan, terlihat adanya beberapa perusahaan (30\%) yang mengomposkan sebagian bahan baku terlebih dahulu. Proses tersebut dilakukan oleh pabrik POG, apabila mendapatkan bahan baku yang benar-benar masih segar. Proses pengomposannya juga tidak sempurna, tetapi lebih bersifat menumpuk bahan baku begitu saja. Atau lebih cocok kalau proses tersebut disebut sebagai upaya pengeringan atau penampungan bahan baku untuk dijadikan sebagai stock. 


\subsection{Karakteristik Proses Produksi POG}

Karakteristik proses produksi yang dilakukan oleh sebagian besar pabrik POG adalah sebagai berikut:

\section{1) Penumpukan Bahan Baku}

Proses ini dilakukan oleh sebagian kecil pabrik POG (30\%) terhadap bahan baku berupa pupuk organik yang dianggap masih segar dan atau masih basah. Prosesnya dilakukan dengan menumpuk bahan baku begitu saja dan mendiamkannya untuk beberapa lama sampai diyakini bahan baku tersebut telah kering atau telah siap untuk diproses menjadi POG. Seharusnya pada proses ini bukan hanya menumpuk bahan baku begitu saja, tetapi melakukan proses pengomposan yang benar, yaitu dengan mengoptimalkan beberapa parameter yang dipersyaratkan dalam proses pengomposan 2,3,4,5\&6). Proses pengomposan terhadap bahan baku tersebut, sebaiknya dilakukan oleh pabrik POG, agar diperoleh bahan baku POG yang berkualitas berupa kompos yang bermutu.

\section{2) Penggilingan (Crushing)}

Kegiatan ini biasanya merupakan proses lanjut dari proses penumpukan, karena dari bahan baku yang ditumpuk, biasanya banyak yang menggumpal. Proses tersebut sekaligus juga berfungsi untuk menghancurkan bahan baku sehingga fraksinya menjadi lebih kecil. Proses penggilingan biasanya dilakukan dengan menggunakan mesin crusher.

\section{3) Penyaringan}

Proses penyaringan dilakukan untuk mendapatkan ukuran fraksi bahan baku yang halus. Proses ini biasanya dilakukan dengan saringan getar (vibrating screen) atau saringan putar (rotating screen). Ukuran saringan yang digunakan bervariasi, ada yang menggunakan saringan berukuran $5 \mathrm{~mm}$ dan ada juga yang menggunakan ukuran $10 \mathrm{~mm}$. Untuk mendapatkan bentuk POG yang bagus, maka sebaiknya ukuran saringan adalah $5 \mathrm{~mm}$. Bahan baku berupa pupuk organik yang tidak lolos saringan (yang kasar), biasanya dikembalikan lagi ke proses penumpukan.

\section{4) Pencampuran Bahan Baku}

Proses ini merupakan pencampuran bahan baku utama (pupuk organik) dengan bahan baku tambahan (filler), menggunakan mesin mixer atau mollen. Umumnya pabrik POG memulai proses pembuatan POG sejak proses pencampuran bahan baku. Sedangkan proses yang lain sebelumnya, dilakukan oleh perusahaan lain yang merupakan mitra dari pabrik POG.

\section{5) Proses Granulasi}

Proses granulasi atau pembuatan pupuk organik menjadi berbentuk granul merupakan inti dari proses pembuatan POG, yang dilakukan oleh seluruh pabrik POG dengan menggunakan pan granulator. Kemiringan dari pan granulator umumnya $45^{\circ}$ dengan kecepatan putar sekitar 20 putaran permenit. Kemiringan dan kecepatan putar tersebut merupakan ukuran yang optimal untuk suatu proses pembuatan POG yang baik. Proses granulasi tersebut dilakukan dengan 2 (dua) sistem, yaitu ada perusahaan yang menggunakan sistem batch dan ada pula yang menggunakan sistem continuos. Yang dimaksud dengan sistem batch adalah penggunaan input bahan baku yang pertama dengan yang berikutnya terpisah (tidak terus menerus) untuk menghasilkan output yang juga terpisahpisah, atau dengan kata lain proses produksinya terputus-putus. Sedangkan yang dimaksud dengan sistem continuos adalah proses input bahan baku yang terus menerus untuk menghasilkan output POG yang juga terus menerus. 
Manfaat dari penggunaan sistem batch adalah diperolehnya butiran POG yang lebih baik, sedangkan manfaat dari sistem continous adalah diperolehnya kapasitas produksi yang lebih besar.

\section{6) Pengeringan}

Proses pengeringan dilakukan oleh semua pabrik POG dengan menggunakan rotary drier. Alat ini digunakan agar secara cepat dan dalam jumlah banyak dapat menurunkan kadar air POG menjadi dibawah $20 \%$ sesuai Permentan No. 28 Tahun $2009{ }^{1)}$. Proses pengeringan dengan melibatkan suhu yang tinggi akan berdampak negatif terhadap kualitas POG, karena akan mematikan sebagian besar mikroba fungsional yang secara alamiah sudah ada di dalam POG.

\section{7) Pendinginan}

Alat yang digunakan untuk menurunkan suhu secara cepat adalah rotary cooler. Alat ini digunakan juga oleh sebagian besar pabrik POG, dalam rangka mengejar target produksi.

\section{8) Penyaringan POG}

Proses penyaringan dilakukan untuk membuat ukuran butiran POG sesuai Permentan 28 Tahun 2009, yaitu 2-5 mm. Proses penyaringan dilakukan dengan menggunakan saringan getar (vibrating screen) dan ada pula yang menggunakan saringan putar (rotating screen).

\section{9) Pengayaan Mikroba Fungsional}

Proses ini perlu mendapatkan perhatian karena tujuannya adalah dalam rangka memberikan dan meningkatkan mikroba fungsional dalam jumlah tertentu ke dalam POG sesuai Permentan No. 28 Tahun $2009^{1)}$, dengan cara menyemprotkan pupuk hayati tertentu. Karena yang disemprotkan adalah makhluk hidup, maka prosesnya harus dilakukan secara hati-hati dan diusahakan agar mikroba tersebut dapat tetap hidup, dengan minimal jumlah sesuai ketentuan Permentan 28. Proses ini dilakukan oleh pabrik POG dengan cara yang berbedabeda. Ada yang menyemprotkan pupuk hayati pada saat pencampuran bahan baku dengan menggunakan mixer. Kalau dilihat secara sepintas, proses tersebut memang praktis dan mudah untuk dilakukan. Namun kalau diamati secara cermat, proses tersebut menjadi percuma, karena mikroba yang diberikan dalam bentuk pupuk hayati, akan mati pada saat proses pengeringan menggunakan rotary drier. Ada yang menyemprotkan pada saat POG sedang didinginkan di dalam rotary cooler. Proses inipun juga tidak efektif karena suhu POG masih tinggi, sehingga juga akan mematikan mikroba yang disemprotkan. Yang lain menyemprotkan mikroba ke POG, langsung pada saat POG baru keluar dari rotary drier. Pada kondisi tersebut suhu POG masih cukup panas, sehingga juga kurang efektif untuk penyemprotan mikroba fungsional. Kondisi yang paling ideal adalah yang dilakukan oleh sebagian pabrik POG, yaitu yang melakukan penyemprotan dengan cara mengangin-anginkan POG yang baru keluar dari rotary drier atau rotary cooler terlebih dahulu. Setelah suhu POG benar-benar dingin, maka POG tersebut kemudian dimasukkan kembali kedalam pan granulator dan kemudian disemprotkan dengan pupuk hayati yang telah ditetapkan. Dengan suhu yang sudah dingin diharapkan tingkat kematian mikroba menjadi sangat kecil. Sedangkan tujuan penyemprotan pupuk hayati menggunakan pan granulator adalah untuk mengkondisikan penyemprotan yang merata. Cara penyemprotan seperti yang terakhir inilah yang kemudian disarankan ke seluruh pabrik POG yang disurvai, yang ternyata cara tersebut kemudian diikutinya. 
10) Pengarungan

Proses ini dilakukan dengan menggunakan karung yang telah ditentukan dan merupakan proses yang umum dilakukan. Proses pengarungannya ada yang menggunakan mesin secara manual dan ada pula yang sudah menggunakan mesin secara otomatis (continuos).

Keseluruhan proses produksi POG tersebut, digambarkan dalam bagan alir seperti tertera pada Gambar 1.

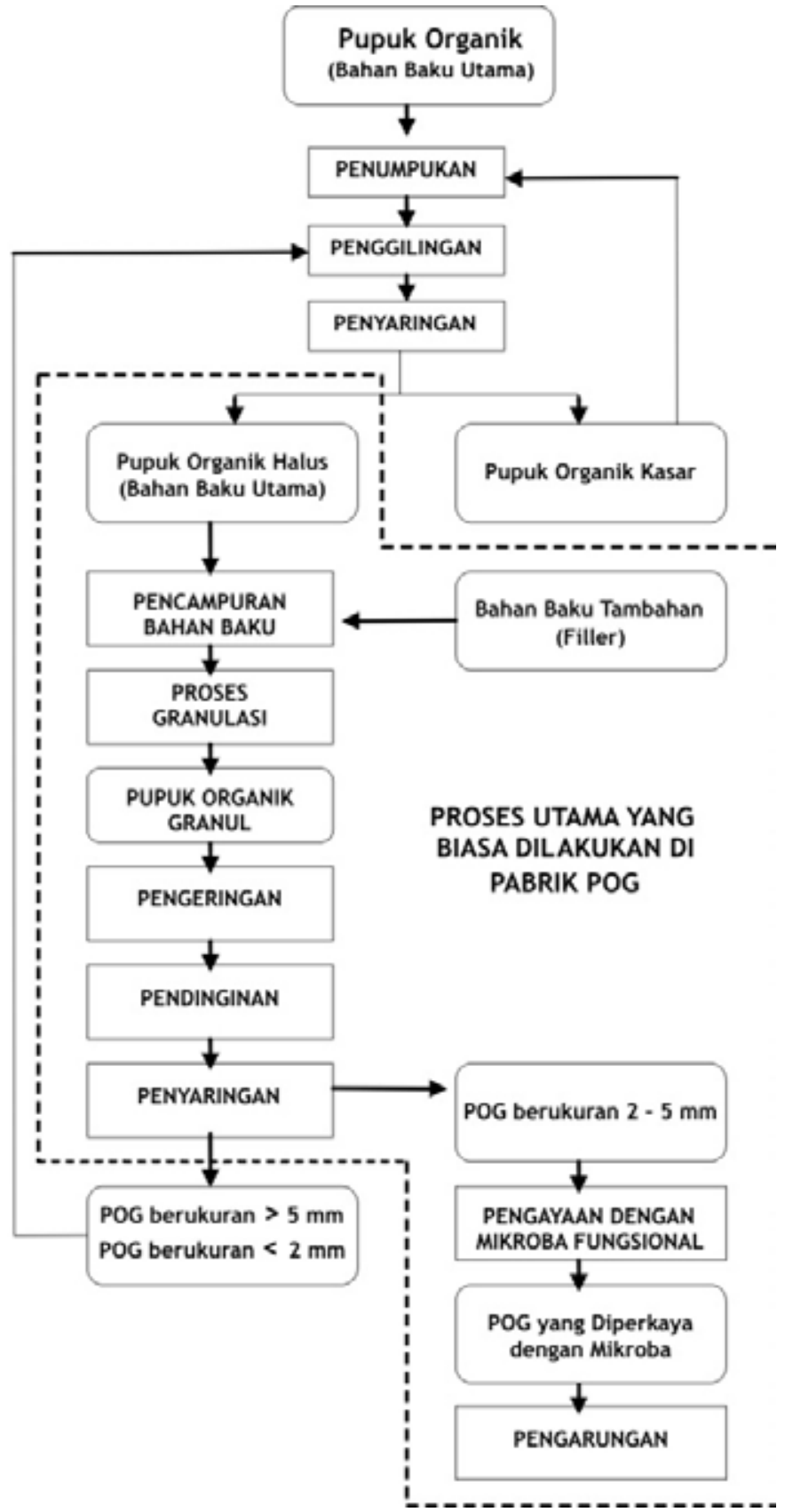

Gambar 1. Bagan Alir Proses Produksi Pupuk Organik Granul (POG) 


\section{KESIMPULAN DAN SARAN}

\subsection{Kesimpulan}

Berdasarkan hasil penelitian ini, dapat ditarik kesimpulan sebagai berikut:

1. Kondisi plant/pabrik POG umumnya berupa sarana dan prasarana yang lebih untuk mendukung suatu proses yang bersifat fisik, dan hampir tidak ada sarana dan prasarana yang mendukung suatu proses yang bersifat biologis, kecuali proses pengayaan dengan mikroba fungsional.

2. Sebagai konsekuensi dari sarana dan prasarana yang ada, maka proses pembuatan pupuk organik granul (POG), umumnya mengandalkan proses fisik/ mekanis, dengan tanpa melalui proses biologis terlebih dahulu yang biasanya dikenal dengan proses pengomposan. Dengan cara tersebut, maka bahan baku organik yang dapat digunakan menjadi terbatas.

3. Bahan baku utama berupa pupuk organik yang paling disukai adalah yang berasal dari bahan organik yang sudah berbentuk halus seperti blotong dan kotoran hewan (kohe), terutama kotoran sapi dan kotoran ayam.

4. Proses utama yang umumnya dilakukan oleh pihak perusahaan untuk memproduksi POG adalah pencampuran bahan baku, proses granulasi, pengeringan, pendinginan, penyaringan, pengayaan dengan mikroba fungsional dan pengarungan.

\subsection{Saran}

Sedangkan dari hasil penelitian dan kesimpulan dapat disarankan hal-hal sebagai berikut:

1. Bahan baku POG sebaiknya tidak hanya mengandalkan kotoran hewan, blotong, limbah sisa budidaya jamur saja. Seluruh potensi bahan organik yang sangat melimpah di Indonesia (termasuk sampah organik), seharusnya dioptimalkan untuk dijadikan POG.

2. Proses pengayaan mikroba fungsional, seharusnya dilakukan setelah suhu dari produk POG sudah dingin, yaitu dengan mengangin-anginkan terlebih dahulu produk POG yang keluar dari proses pendinginan menggunakan rotary cooler.

3. Perlunya panduan tatacara pembuatan pupuk organik yang akan dijadikan sebagai bahan baku POG.

\section{DAFTAR PUSTAKA}

1. Menteri Pertanian Republik Indonesia, 2009. Peraturan Menteri Pertanian No 28/Permentan/SR.130/5/2009, Tentang Pupuk Organik, Pupuk Hayati dan Pembenah Tanah. Berita Negara Republik Indonesia Tahun 2009 Nomor 137.

2. Golueke, C.G., 1977. Biological Processing: Composting and Hydrolysis; In Handbook of Solid Waste Management. Van Nostrand Reinhold Company, New York.

3. Haug, R.T., 1980. Compost Engineering, Principles and Practice, An Arbor Science Publisher Inc., Michigan.

4. Tchobanouglous, G., H. Theisen and S. Vigil, 1993. Integrated Solid Waste Management, Engineering Principles and Management Issues, Mc Graw-Hill Inc., USA.

5. Epstein, E., 1997. The Science of Composting. Technomic Publishing Company Inc., USA.

6. Wahyono, S., F.L. Sahwan dan F. Suryanto, 2003. Menyulap Sampah Menjadi Kompos. Pusat Pengkajian dan Penerapan Teknologi Lingkungan BPPT, Jakarta.

7. Iswandi, A., 2010. Peranan Pupuk Organik dan Pupuk Hayati dalam Peningkatan Produktivitas Beras 
Berkelanjutan. Makalah pada Seminar Nasional Peranan Pupuk NPK dan Organik dalam Meningkatkan Produksi dan Swasembada Beras Berkelanjutan. Balai Besar Litbang Sumberdaya Lahan Pertanian, Badan Penelitian dan Pengembangan Pertanian, Kementerian Pertanian, Jakarta.

8. Kementerian Pertanian Republik Indonesia, 2010. Pemulihan Kesuburan Tanah pada Lahan Sawah Berkelanjutan. Badan Litbang Pertanian dan Ditjen Tanaman Pangan, Jakarta.

9. Kementerian Pertanian Republik
Indonesia, 2010. Go Organik 2010.

10.Husen, E., R. Saraswati dan R.D. Saraswati, 2006. Rizobakteri Pemacu Tumbuh Tanaman; di dalam Pupuk Organik dan Pupuk Hayati (Organic Fertilizer and Biofertilizer). Balai Besar Litbang Sumberdaya Lahan Pertanian, Badan Penelitian dan Pengembangan Pertanian, Bogor.

11. Kementerian Pertanian Republik Indonesia, 2010. Pelaksanaan PSO Subsidi Benih dan Pupuk Tahun Anggaran 2010. Direktorat Jenderal Tanaman Pangan, Jakarta.

\section{GAMBAR-GAMBAR PROSES PEMBUATAN PUPUK ORGANIK GRANUL (POG)}

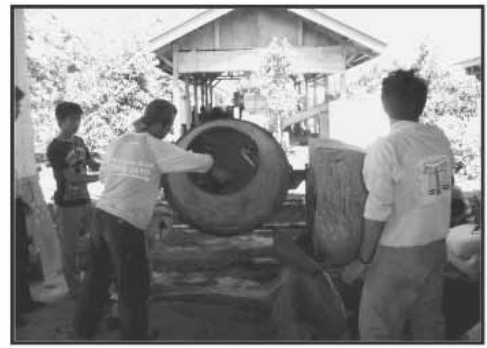

Gambar 1. Pencampuran Pupuk Organik (Bahan Baku Utama) dengan Filler

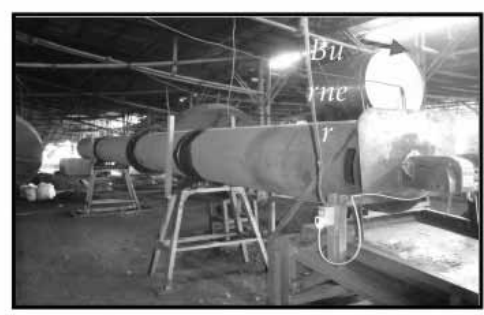

Gambar 3. Proses Pengeringan POG Menggunakan Rotary Drayer

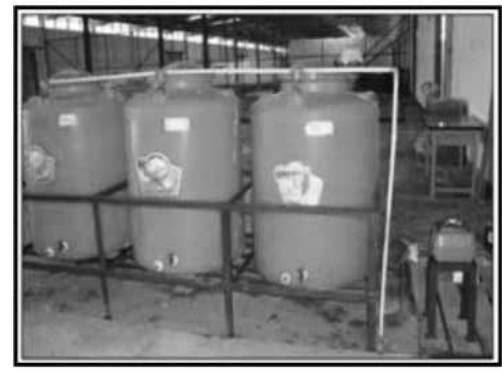

Gambar 5. Penyiapan Larutan Mikroba Fungsional untuk Penyemprotan POG

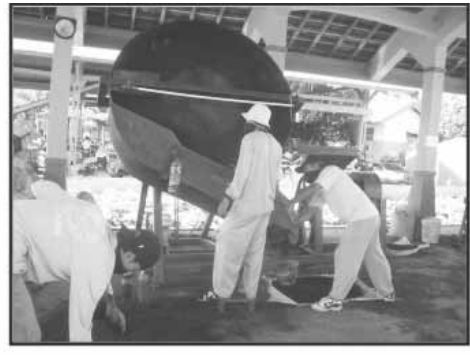

Gambar 2 . Proses Granulasi

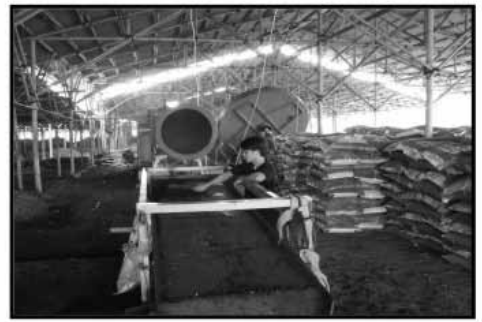

Gambar 4. Proses Penyaringan POG

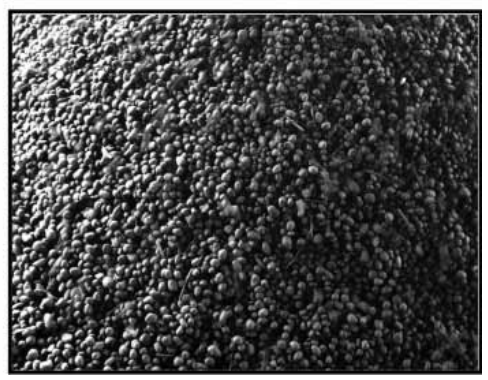

Gambar 6. Produk POG yang Sudah Diperkaya dengan Mikroba 